\title{
Sistem Informasi Manajemen Ekstrakurikuler Berbasis Web Menggunakan Metode Rapid Application Development
}

\author{
Agus Cahyo Nugroho \\ Universitas Katolik Soegijapranata, Semarang, Jawa Tengah \\ agus.nugroho@unika.ac.id
}

(Naskah masuk: 5 Okt 2021, direvisi: 17 Okt 2021, diterima: 29 Okt 2021)

\begin{abstract}
Abstrak
Seiring perkembangan teknologi maka dikembangkan sistem informasi yang mampu mengelola penyelenggaraan kegiatan ekstrakurikuler, khususnya yang berkaitan dengan siswa sekolah. Tujuan penelitian ini adalah membuat sistem informasi manajemen ekstrakurikuler siswa untuk digunakan oleh koordinator ekstrakurikuler dalam mengelola data siswa peserta ekstrakurikuler di sekolah. Sistem informasi pengelolaan ekstrakurikuler siswa ini dikembangkan dalam bentuk web menggunakan Framework PHP Laravel. Sistem informasi pengelolaan ekstrakurikuler siswa ini dikembangkan dengan metode Rapid Application Development (RAD) dengan tujuan membuat sistem informasi web secepat mungkin. Sistem informasi pengelolaan ekstrakurikuler siswa berbasis web ini mampu mengelola (menambah, memperbarui, dan menghapus) data ekstrakurikuler yang ditawarkan dan melihat rekapitulasi data peserta dari masing-masing ekstrakurikuler. Sistem informasi pengelolaan ekstrakurikuler siswa ini terbukti mampu meningkatkan kinerja bagian akademik sekolah dalam mengelola kegiatan ekstrakurikuler di sekolah tersebut.
\end{abstract}

Kata Kunci: Sistem Informasi, Rapid Application Development, Laravel, PHP Framework

\section{Web-Based Extracurricular Management Information System Using Rapid Application Development Method}

\begin{abstract}
Along with the development of technology, an information system is developed that is able to manage the implementation of extracurricular activities, especially those related to school students. The purpose of this research is to create a student extracurricular management information system to be used by the extracurricular coordinator in managing the data of extracurricular students participating in the school. This student extracurricular management information system was developed in web based using the Laravel PHP Framework. This student extracurricular management information system was developed using the Rapid Application Development (RAD) method with the aim of creating a web information system as quickly as possible. This web-based student extracurricular management information system is able to manage (add, update, and delete) the extracurricular data offered and view the recapitulation of participants data from each extracurricular. This student extracurricular management information system is proven to be able to improve the performance of the school's academic department in managing extracurricular activities at the school.
\end{abstract}

Keywords: information system, Rapid Application Development, Laravel, php Framework

\section{PENDAHULUAN}

Semua organisasi membutuhkan sistem informasi agar berfungsi secara efektif. Setiap sistem informasi, baik untuk bisnis swasta, perusahaan multinasional, atau kantor pemerintah negara industri besar, terdiri dari sejumlah komponen. Dengan demikian sistem informasi merupakan sistem sosial yang menggunakan teknologi informasi [1]. Objek dari desain sistem yang baik harus mengembangkan sistem yang memungkinkan organisasi menggunakan sumber daya mereka supaya lebih efektif dan efisien serta pada saat 
yang sama meningkatkan kualitas kerja mereka yang bekerja untuk organisasi tersebut.

Penulis menyelenggarakan kegiatan penelitian dengan berdasarkan metode Rapid Application Development (RAD) untuk meningkatkan kualitas kerja organisasi. Metode Rapid Application Development (RAD) pada pemrograman web diimplementasikan menggunakan Framework PHP. Framework PHP menyederhanakan pengembangan sistem informasi web yang kodenya menggunakan PHP dengan menyediakan struktur dasar dalam pengembangan aplikasi web [2]. Selain itu, kerangka kerja PHP membantu mempopulerkan Rapid Application Development (RAD), efisiensi waktu, membantu pengembangan aplikasi yang lebih stabil, dan mengurangi redudansi kode oleh developer. PHP Framework juga bisa membantu pemula dalam mengembangkan aplikasi yang lebih stabil dengan menjamin interaksi dan pemrograman database yang lebih baik pada lapisan presentasi. Hal ini menyebabkan untuk penggunaan waktu yang lebih banyak dalam pembuatan aplikasi web yang sesungguhnya daripada menggunakan waktu dalam penulisan kode yang berulang. Ide umum pada fungsi PHP Framework sering dikenal dengan Model View Controller (MVC). MVC merupakan contoh nyata arsitektur pemrograman yang mengisolasi logika bisnis dari antarmuka pengguna, sehingga memungkinkan untuk memodifikasinya secara terpisah [2].

\section{METODE PENELITIAN}

\section{A. Sistem Informasi Manajemen}

Pesatnya perkembangan dan kemajuan teknologi menuntut seseorang untuk beradaptasi menyesuaikan diri mengikuti perkembangan dan kemajuan tersebut. Perkembangan dan kemajuan teknologi ini telah banyak digunakan di berbagai bidang. Perkembangan dan kemajuan teknologi ini juga memberikan peluang yang besar untuk pengelolaan dan pemanfaatan informasi secara lebih efisien dan akurat. Teknologi yang diterapkan dengan baik akan mampu mengurangi berbagai tahapan dalam proses kerja yang semula dilakukan secara manual akan tergantikan dengan sistem. Pemanfaatan teknologi tersebut menjadi dasar dalam penerapan Sistem Informasi Manajemen (SIM) [3] - [5] Sistem Informasi Manajemen dapat diimplementasikan untuk mendorong efisiensi kinerja [6], [7] dan kepuasan pengguna dalam suatu organisasi.

Sistem Informasi Manajemen (SIM) menurut Ersoy dan Celebi merupakan kombinasi dari sumber daya manusia dan komputer yang menghasilkan pengumpulan, penyimpanan, pengambilan, komunikasi dan penggunaan data dengan tujuan efisiensi manajemen operasional sehingga menjadi siap digunakan dalam perencanaan bisnis [8]. SIM memfasilitasi manajemen dengan membuat laporan terstruktur dan diringkas secara berkala dan berulang. Laporan tersebut kemudian digunakan sebagai dasar dalam proses pengambilan keputusan.

\section{B. Metode Rapid Application Development}

Metodologi RAD merancang desain perangkat lunak dengan memfasilitasi tahap development dengan lebih cepat dan dapat dihandalkan. Penghematan waktu adalah kelebihan RAD jika dibandingkan metode pengembangan perangkat lunak yang lain dimana metode lain membutuhkan proses dengan waktu yang lebih lama. Pengembangan perangkat lunak berdasarkan RAD adalah peluang lebih baik dalam pengembangan aplikasi [9].

Metode RAD tidak berfokus terhadap perencanaan melainkan lebih berfokus di pembangunan. Oleh sebab itu, beberapa tahap pengembangan bisa dilaksanakan secara bersama-sama. Tiap siklus terdiri dari dua tahap yaitu development dan testing, yang disebut dengan modul. Input dari ketua proyek diperoleh saat tiap bagian unit telah selesai dikembangkan. Metode ini sesuai diterapkan pada bisnis skala mikro, sedang, atau besar, namun harus ada kepastian proyek tersebut bisa dipecah ke dalam beberapa unit. Metodologi ini sesuai untuk perusahaan kecil, menengah atau besar, namun penting untuk diingat melakukan pembagian proyek menjadi beberapa unit seperti yang bisa dilihat di Gambar 1 [9].

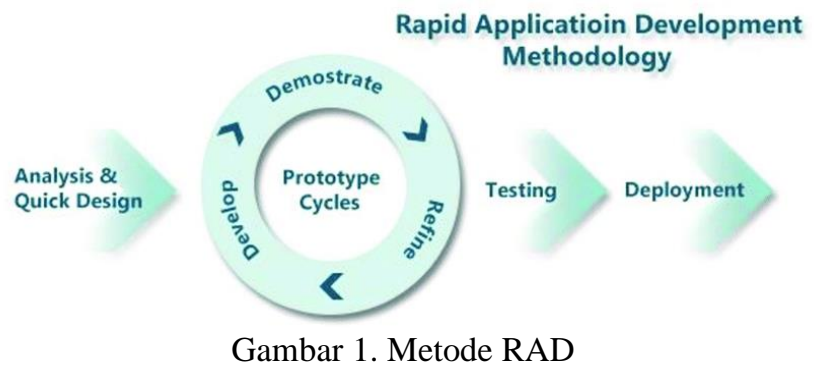

\section{Penelitian Sebelumnya}

Metode Rapid Application Development (RAD) adalah proses adaptasi yang berasal dari sequential linear model yaitu proses pembangunan perangkat lunak dapat dilakukan dengan cepat dikarenakan penggunaan prinsip pembangunan berdasar komponen [10].

Penelitian menggunakan metode RAD sebelumnya yaitu penelitian yang dilakukan oleh Hartono merupakan case study menggunakan sumber data kualitatif maupun kuantitatif. Cara memperoleh data yang digunakan melalui interview maupun pengamatan langsung. Saat mengembangkan sistem, dipilih menggunakan RAD dikarenakan lebih cepat dalam menghasilkan prototipe. Tahap dalam metode RAD yang dilaksanakan mulai dari observasi di awal, identifikasi masalah, identifikasi kebutuhan, identifikasi biaya, perancangan basis data, dan pembuatan prototipe [11].

Penelitian lain menggunakan Laravel menyimpulkan bahwa Laravel cocok untuk digunakan pembuatan aplikasi dengan skala besar dalam waktu yang lebih cepat bahkan disaat kondisi sumber daya manusia yang minim pengalaman [12].

Penelitian terdahulu sudah pernah dilaksanakan Mediana yaitu membuat sistem Helpdesk dalam bentuk web memakai kerangka Laravel dengan memanfaatkan RAD. Kesimpulannya, sistem Helpdesk yang dikembangkan dapat meningkatkan kualitas kerja pegawai terkait tata kelola data 
dan mengatasi laporan terkait masalah di lapangan secara lebih cepat [13].

\section{Metode Penelitian}

Metode penelitian ini dilakukan merupakan lima tahapan antara lain: analisa kebutuhan sistem maupun masalah yang dihadapi, studi pustaka, perancangan, pengembangan aplikasi, penerapan, hasil kesimpulan kemudian evaluasi.

\section{C.1. Analisis Kebutuhan maupun Masalah}

Pada bagian awal peneliti melaksanakan observasi secara langsung di tempat penelitian. Melihat sistem yang digunakan kemudian melakukan wawancara dengan koordinator kegiatan ekstrakurikuler di SMA Karangturi.

\section{C.2. Studi Pustaka dan Desain}

Setelah melakukan analisis kebutuhan maupun permasalahan, tahap berikutnya adalah melaksanakan studi pustaka terhadap penelitian sejenis yang pernah dilaksanakan sebelumnya, menganalisis masukan-masukan pada penelitian terdahulu, memilih yang cocok dan menerapkannya pada penelitian yang sedang dilakukan.

Penelitian kemudian lanjut ke tahap berikutnya dengan proses perancangan antar muka, perancangan alur program, dan perancangan basis data. Perancangan antar muka menggambarkan berbagai macam form yang digunakan oleh program, komponen form beserta display informasi apakah suatu proses berhasil atau tidak. Rancangan alur program digunakan untuk menginformasikan jalannya program dari tahap awal sampai tahap akhir. Alur logika program ini dapat digambarkan dengan Use Case Diagram. Desain database digunakan untuk merancang database relasional yang digunakan dalam program. Perancangan basis data ini dapat digambarkan dengan Entity Relationship Diagram yang kemudian dirinci melalui Kamus Data.

\section{C.3. Pengembangan Aplikasi}

Basis data merupakan pondasi dari aplikasi sehingga setelah perancangan basis data selesai maka proses selanjutnya dilanjutkan dengan pembuatan aplikasi. Aplikasinya sendiri dikembangkan dengan menggunakan Framework PHP yang mendukung metode Rapid Application Development (RAD). Framework PHP yang dipilih adalah Laravel. Tampilan aplikasi akan menggunakan Template CSS Boostrap untuk mempercepat proses pembuatan aplikasi.

\section{C.4. Penerapan}

Setelah aplikasi selesai dibangun, tahap berikutnya yaitu menerapkan aplikasi tersebut pada objek penelitian. Hal tersebut dilaksanakan supaya aplikasi tersebut dapat menjadi acuan untuk koordinator dalam mengelola berbagai macam organisasi ekstrakurikuler dan mahasiswa peserta. Selain itu juga menjadi acuan yayasan dalam memantau kemajuan kegiatan ekstrakurikuler di sekolah.

\section{C.5. Hasil Kesimpulan dan Evaluasi}

Hasil kesimpulan dan evaluasi adalah tahap akhir dari penelitian ini dimana peneliti akan memformulasikan hasil observasi setelah aplikasi diterapkan di lokasi penelitian. Selain itu output tambahan dari penelitian ini adalah buku manual aplikasi telah diberikan kepada pihak sekolah. Pada tahap ini juga akan dilaksanakan observasi dan feedback kirakira apa yang mungkin dikembangkan untuk penelitian selanjutnya.

\section{HASIL DAN PEMBAHASAN}

Pada Gambar 2 berikut ini adalah Use Case Diagram yang merupakan visualisasi lengkap dari sistem informasi manajemen ekstrakurikuler. Tiga aktor pada Use Case Diagram adalah Pengguna, Operator, dan Admin. Pengguna tidak perlu login ke sistem untuk dapat melihat daftar siswa yang mendaftar pada ekstrakurikuler tertentu. Sedangkan Operator dan Admin harus login lebih dulu ke sistem untuk dapat mengakses berbagai macam fitur sistem. Operator dan Admin setelah berhasil login ke sistem dapat mengakses fitur CRUD siswa untuk menambah data siswa baru beserta ekstrakurikuler yang diambilnya, mengubah data siswa tertentu beserta ekstrakurikuler yang diambilnya, dan menghapus data siswa tertentu termasuk ekstrakurikuler yang sudah diambil. Selain itu, Operator dan Admin juga dapat menggunakan fitur CRUD untuk mengelola referensi kelas dan ekstrakurikuler. Sedangkan perbedaan antara Operator dan Admin adalah Admin dapat mengakses fitur CRUD User. Fitur ini secara khusus diberikan kepada Admin karena hanya Admin yang diizinkan untuk mengelola hak akses pengguna tertentu.

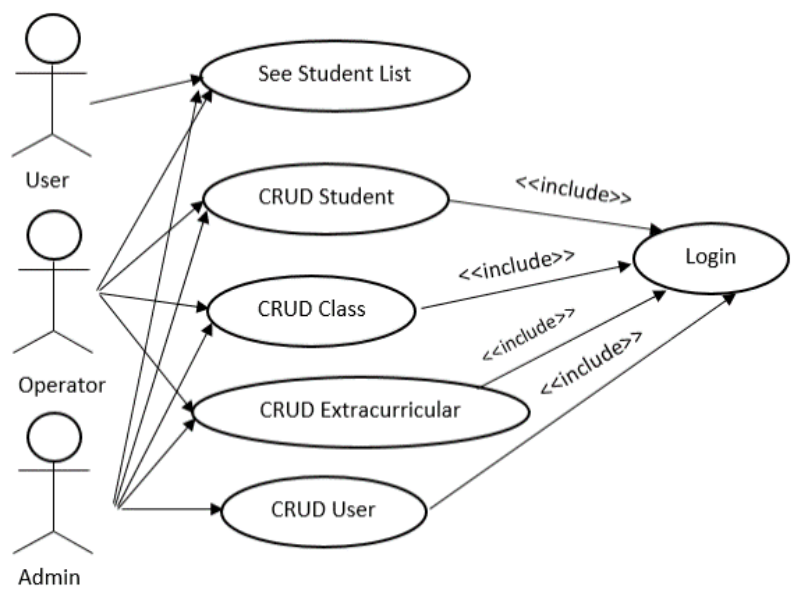

Gambar 2. Use Case Diagram

Struktur tabel dan relasi antar tabel yang diacu dalam tahap desain sistem informasi manajemen ekstrakurikuler bisa dilihat pada Tabel 1 sampai dengan Tabel 5.

Tabel 1. Hobi.sql

\begin{tabular}{lll}
\hline \multicolumn{1}{c}{$\begin{array}{c}\text { Column } \\
\text { Name }\end{array}$} & Data Type & \multicolumn{1}{c}{ Deskripsi } \\
\hline id & int $(10)$ & Primary Key \\
\hline nama_hobi & varchar $(30)$ & Name of the hobbies \\
\hline Created_at & timestamp & Tell when the data is Created \\
\hline Updated_at & timestamp & Tell when the data is Updated \\
\hline
\end{tabular}


Tabel 2. Hobi_siswa.sql

\begin{tabular}{lll}
\hline $\begin{array}{l}\text { Column } \\
\text { Name }\end{array}$ & Data Type & Deskripsi \\
\hline id_siswa & int $(10)$ & Foreign Key from table siswa \\
\hline id_hobi & int $(10)$ & Foreign Key from table hobi \\
\hline Created_at & timestamp & Tell when the data is Created \\
\hline Updated_at & timestamp & Tell when the data is Updated \\
\hline
\end{tabular}

Tabel 3. Kelas.sql

\begin{tabular}{lll}
\hline $\begin{array}{c}\text { Column } \\
\text { Name }\end{array}$ & Data Type & \multicolumn{1}{c}{ Deskripsi } \\
\hline id & int $(10)$ & Primary Key \\
\hline nama_kelas & varchar(20) & Name of the class \\
\hline Created_at & timestamp & Tell when the data is Created \\
\hline Updated_at & timestamp & Tell when the data is Updated \\
\hline
\end{tabular}

Tabel 4. Siswa.sql

\begin{tabular}{lll}
\hline $\begin{array}{l}\text { Column } \\
\text { Name }\end{array}$ & Data Type & Deskripsi \\
\hline id & int(10) & Primary Key \\
\hline nisn & varchar(4) & $\begin{array}{l}\text { National Identifier } \\
\text { Number }\end{array}$ \\
\hline nama_siswa & varchar(50) & $\begin{array}{l}\text { Name of the student } \\
\text { Date of Birth }\end{array}$ \\
\hline janggal_lahir & date & Student sex \\
\hline jenis_kelamin & enum & Foreign Key from table kelas \\
\hline id_kelas & int $(10)$ & Name of the image Uploaded \\
\hline foto & varchar(100) & Tell when the data is Created \\
\hline Created_at & timestamp & Tell when the data is Updated \\
\hline
\end{tabular}

Tabel 5. Telepon.sql

\begin{tabular}{lll}
\hline Column Name & \multicolumn{1}{c}{ Data Type } & \multicolumn{1}{c}{ Deskripsi } \\
\hline id_siswa & int $(10)$ & Foreign Key from table siswa \\
\hline nomor_telepon & varchar(30) & Student phone number \\
\hline Created_at & timestamp & Tell when the data is Created \\
\hline Updated_at & timestamp & Tell when the data is Updated \\
\hline
\end{tabular}

Sedangkan hubungan antar tabel untuk pembuatan sistem informasi manajemen penugasan ditunjukkan pada Gambar 3.

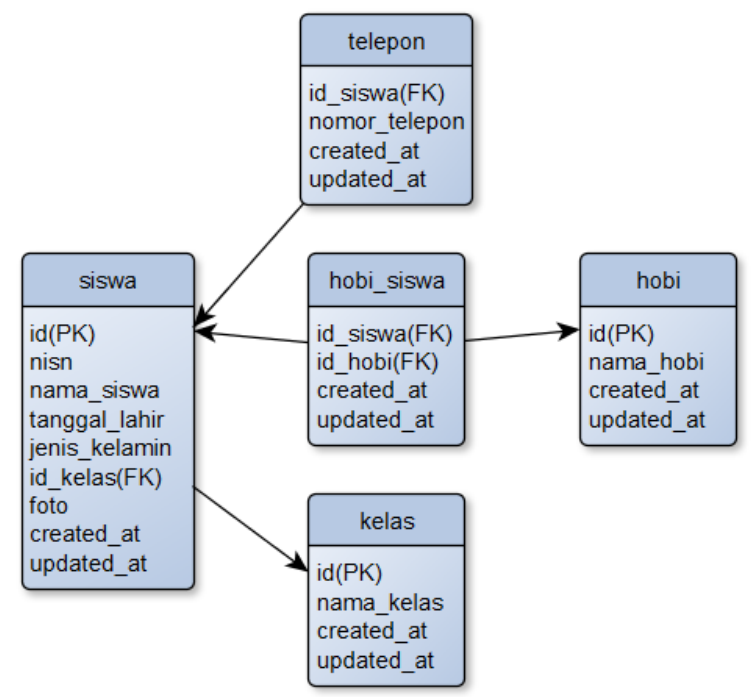

Gambar 3. Entity Relationship Diagram
Dapat terlihat pada diagram alir sistem pada Gambar 4. Ketika pengguna pertama kali mengakses sistem, daftar biodata siswa akan ditampilkan dengan ekstrakurikuler pilihannya. Selain itu dapat dipilih untuk melihat salah satu dari detail siswa ini atau tidak. Jika tidak, maka akan sampai pada pilihan untuk memanipulasi data atau tidak. Jika memilih untuk memanipulasi data, halaman login akan muncul terlebih dahulu. Setelah proses login berhasil maka akan muncul menu halaman siswa, halaman kelas, halaman ekstrakurikuler dan halaman user. Pengguna dapat memanipulasi data melalui empat halaman ini. Proses manipulasi data ini adalah Create, Read, Update and Delete (CRUD).

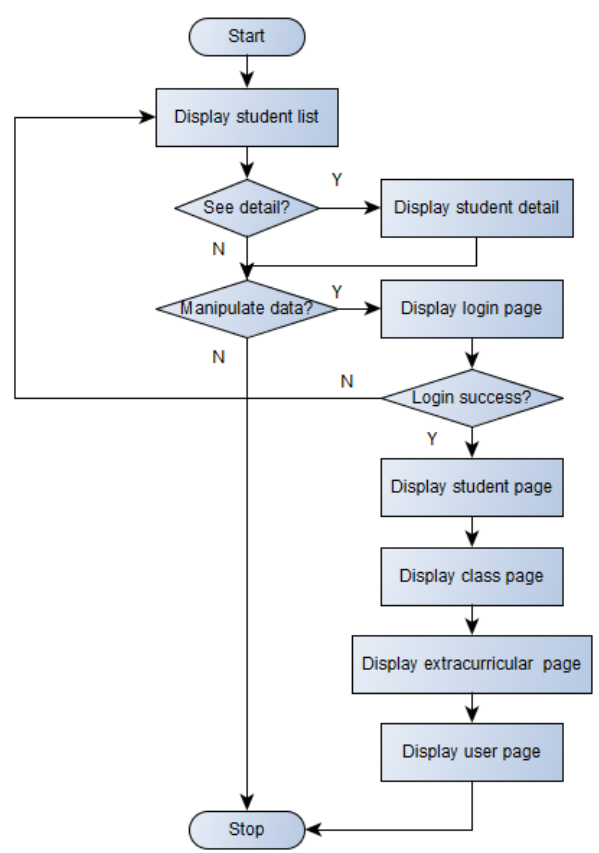

Gambar 4. Flowchart Diagram

Setelah proses perancangan sistem dilakukan tahapan selanjutnya adalah pemrograman. Berikut ini adalah tampilan web sistem informasi pengelolaan ekstrakurikuler untuk halaman utama dimana kita dapat melihat jadwal ekstrakurikuler seperti pada Gambar 5.

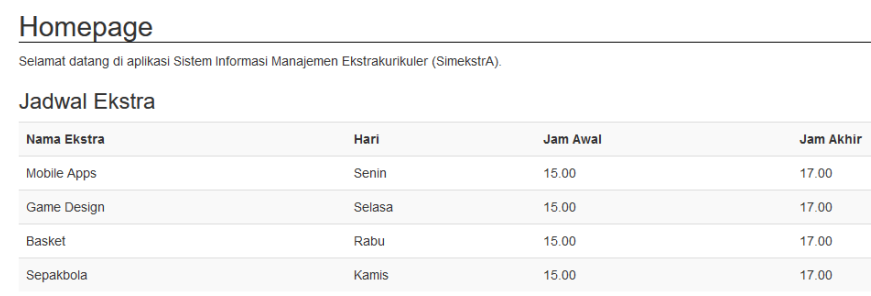

Gambar 5. Halaman Homepage Jadwal Ekstrakurikuler

Sedangkan jika kita tekan menu siswa maka pada halaman ini pengguna dapat melihat daftar siswa beserta ekstrakurikuler yang dipilih seperti pada Gambar 6. 


\begin{tabular}{|c|c|c|c|c|c|c|}
\hline SimekstrA & Siswa & About & & & & \\
\hline \multicolumn{7}{|l|}{ Siswa } \\
\hline -Kelas- & $v$ & -kelamin- & $v$ & Masukkan Nama SIswa & & \\
\hline NISN & Nama & Kelas & TgI Lahir & JK & Telepon & Ekstrakurikuler \\
\hline 1001 & nevin & $x-1$ & 23-04-2018 & L & 081328016505 & Mobile Apps. \\
\hline 1002 & angelyn & $x-2$ & $15-11-2000$ & $\mathrm{P}$ & 08222070788 & Sepakbola. \\
\hline 1003 & richard & $x-2$ & 01-01-1999 & $\mathrm{L}$ & 08222070789 & Game Design. \\
\hline 1004 & nathan & $x-3$ & 22--01-1995 & L & 082220606789 & Basket. \\
\hline 1005 & samuel & $x-1$ & 02-01-1995 & L & & Mobile Apps. \\
\hline
\end{tabular}

Gambar 6. Halaman Daftar Siswa

Jika kita ingin memanipulasi data siswa, referensi kelas, referensi ekstrakurikuler dan hak akses pengguna, pengguna harus login terlebih dahulu ke sistem baik sebagai operator maupun administrator. Halaman login dapat kita lihat pada Gambar 7.

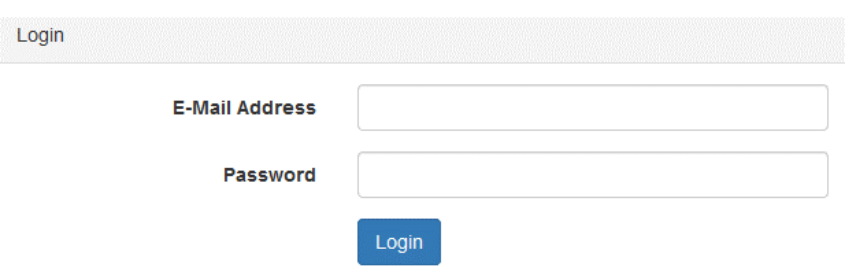

Gambar 7. Halaman Login

Setelah berhasil masuk ke sistem, pengguna dapat memanipulasi data. Ada 3 jenis hak akses, yang pertama adalah pengguna, yang kedua adalah operator, dan yang ketiga adalah administrator. Perbedaannya adalah pengguna hanya dapat melihat daftar siswa dan detailnya. Sedangkan operator dapat memanipulasi data siswa, kelas, dan ekstrakurikuler. Hak akses tertinggi adalah administrator yang memiliki izin tingkat operator plus dapat memanipulasi hak akses pengguna. Kita dapat melihat perbedaan antara halaman menu operator dan administrator pada Gambar 8 dan 9.

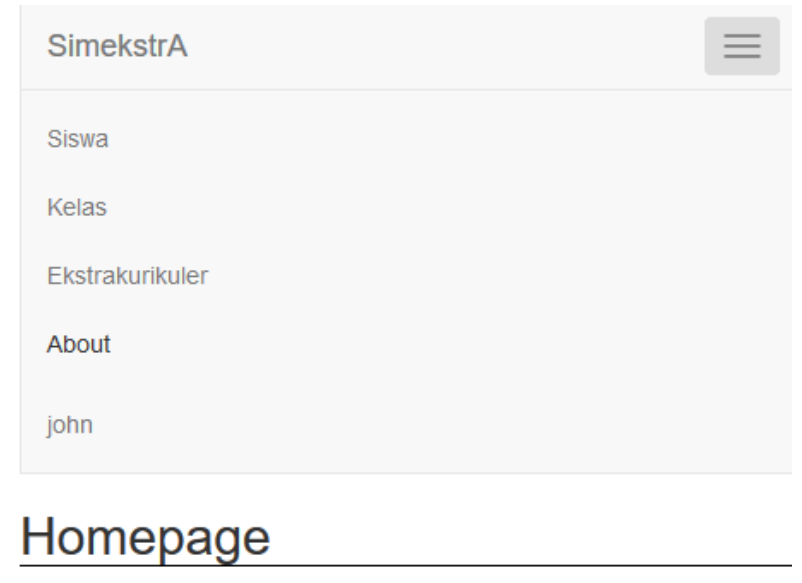

Selamat datang di aplikasi Sistem Informasi Manajemen Ekstrakurikuler (SimekstrA)

Gambar 8. Operator Menu

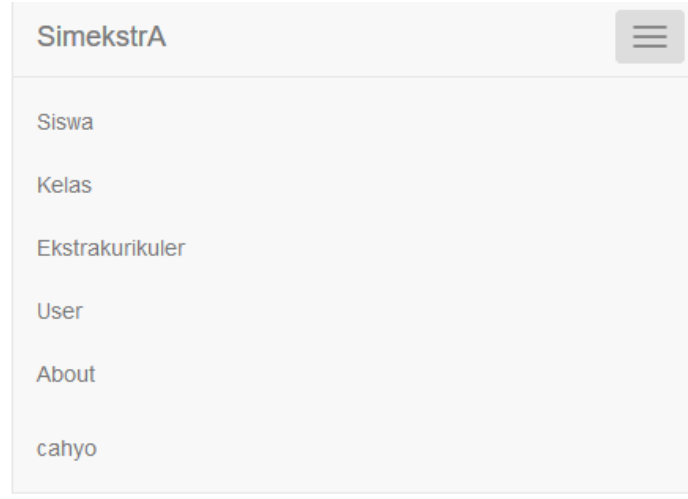

\section{Homepage}

Selamat datang di aplikasi Sistem Informasi Manajemen Ekstrakurikuler (SimekstrA)

\section{Gambar 9. Administrator Menu}

Operator dan Administrator memiliki halaman menu utama yang hanya mirip dengan menu pengguna. Menu pengguna ini merupakan hak khusus bagi administrator karena melalui menu ini kita dapat menambah, mengedit, atau menghapus baik operator maupun administrator. Menu utama administrator terlihat pada Gambar 10. Menu administrator juga terlihat pada Gambar 11.

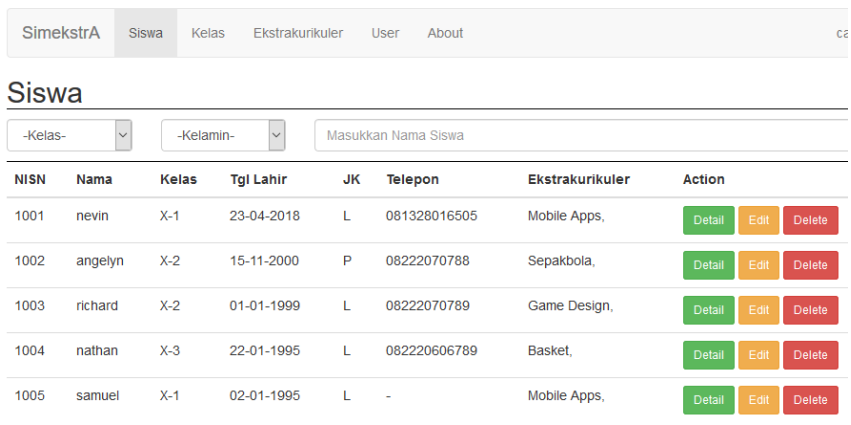

Gambar 10. Menu Utama Administrator

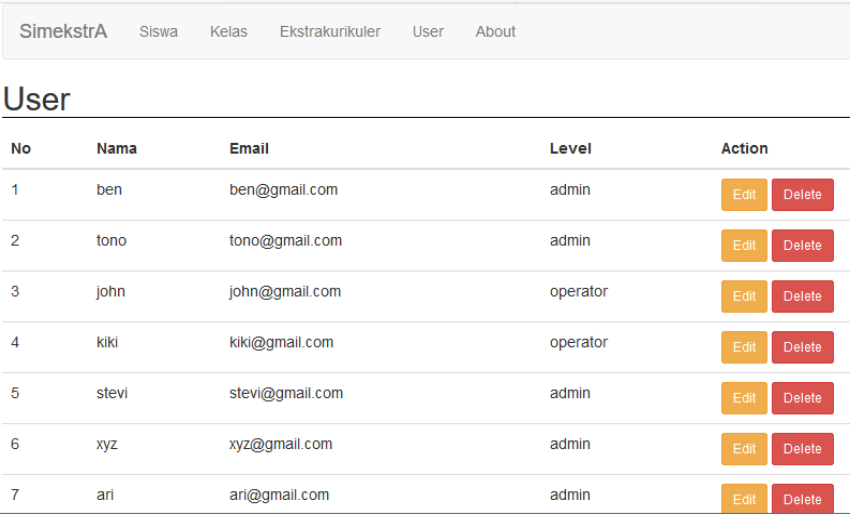

Gambar 11. Menu User Administrator

Setelah sistem selesai kemudian diadakan pengujian menggunakan metode Black Box Testing. 
Tabel 6. Hasil Pengujian Black Box

\begin{tabular}{lllcc}
\hline No & \multicolumn{1}{c}{ Nama } & Output Diharapkan & $\begin{array}{c}\text { Vali } \\
\text { ditas } \\
\text { (Y/T) }\end{array}$ & $\begin{array}{c}\text { \% } \\
\text { Skor }\end{array}$ \\
\hline 1. & Homepage & $\begin{array}{l}\text { Melihat jadwal } \\
\text { esktrakurikuler. }\end{array}$ & Y & 100 \\
\hline 2. & About & $\begin{array}{l}\text { Melihat informasi } \\
\text { terkait sistem. }\end{array}$ & Y & 100 \\
\hline 3. & Siswa & $\begin{array}{l}\text { Melihat daftar siswa } \\
\text { dan ekstrakurikuler } \\
\text { yang diambil. }\end{array}$ & Y & 100 \\
\hline 4. & $\begin{array}{l}\text { Login sebagai } \\
\text { Operator }\end{array}$ & $\begin{array}{l}\text { Masuk ke dalam } \\
\text { sistem sesuai dengan } \\
\text { hak akses Operator. }\end{array}$ & Y & 100 \\
\hline 5. & $\begin{array}{l}\text { Login sebagai } \\
\text { Administrator }\end{array}$ & $\begin{array}{l}\text { Masuk ke dalam } \\
\text { sistem sesuai dengan } \\
\text { hak akses } \\
\text { Administrator. }\end{array}$ & Y & 100 \\
\hline 6. & $\begin{array}{l}\text { Tambah Data } \\
\text { Siswa }\end{array}$ & $\begin{array}{l}\text { Bisa menambahkan } \\
\text { data siswa. }\end{array}$ & Y & 100 \\
\hline 7. & $\begin{array}{l}\text { Edit } \text { Data } \\
\text { Siswa }\end{array}$ & $\begin{array}{l}\text { Bisa mengubah data } \\
\text { siswa. }\end{array}$ & Y & 100 \\
\hline 8. & $\begin{array}{l}\text { Delete } \text { Data } \\
\text { Siswa }\end{array}$ & $\begin{array}{l}\text { Bisa menghapus data } \\
\text { siswa. }\end{array}$ & Y & 100 \\
\hline 9. & $\begin{array}{l}\text { Lihat Detil } \\
\text { Siswa }\end{array}$ & $\begin{array}{l}\text { Bisa melihat detil } \\
\text { siswa. }\end{array}$ & Y & 100 \\
\hline 10. & $\begin{array}{l}\text { Upload } \text { Foto } \\
\text { Siswa }\end{array}$ & $\begin{array}{l}\text { Bisa mengUpload } \\
\text { foto siswa. }\end{array}$ & Y & 100 \\
\hline 11. & $\begin{array}{l}\text { Lihat Rekap } \\
\text { Peserta }\end{array}$ & $\begin{array}{l}\text { Bisa melihat } \\
\text { rekapitulasi jumlah } \\
\text { peserta di masing- } \\
\text { masing } \\
\text { ektrakurikuler. }\end{array}$ & Y & 100 \\
\hline & & & & \\
\hline & & & \\
\hline
\end{tabular}

\section{KESIMPULAN}

Penyelenggaraan kegiatan ekstrakurikuler saat ini belum memenuhi kebutuhan sekolah. Apalagi disebabkan oleh ketergantungan pada kecermatan dan ketelitian bagian akademik sekolah dalam mengelola arsip. Hal tersebut dapat menyebabkan permasalahan ketika tugas atau pekerjaan pada bagian akademik sekolah sedang tinggi sehingga peluang terjadinya kesalahan manusia juga semakin tinggi.

Sistem Informasi Manajemen Ekstrakurikuler yang telah dikembangkan sudah mampu menyelesaikan masalah tersebut dengan cara memfasilitasi dan memudahkan tugas bagian akademik sekolah. File-file tersebut sudah dalam format digital sehingga mempermudah saat akan disimpan dan pendistribusian. Selain itu hal ini juga bermanfaat bagi para siswa dan penyelenggara kegiatan ekstrakurikuler yang dijalani karena sekarang mereka dapat mengakses informasi ekstrakurikuler dari manapun selama ada koneksi internet.

Pengembangan web dengan menggunakan Framework Laravel yang merupakan implementasi dari metode Rapid Application Development juga terbukti dapat mempersingkat waktu pengembangan perangkat lunak. Namun masih ada halhal yang dapat dikembangkan lagi terutama mengenai UI / UX. Maka kedepannya peneliti dapat memikirkan terkait pengembangan aplikasi mobile dari Sistem Informasi web ini.

\section{REFERENSI}

[1] Piercy, N.F. (Ed.). (2018). Management Information Systems: the Technology Challenge (Vol. 40). Routledge.

[2] Laaziri, M., Benmoussa, K., Khoulji, S. \& Kerkeb, M. L. (2019). A Comparative Study of PHP Frameworks Performance. Procedia Manufacturing, Vol. 32, pp. 864871.

[3] Lazim, D., Shah, Z.A., Saedudin, R.R., Kasim, S., Azadin, A.A., Hidayat, R., ... \& Arief, I. (2018). Information Management and PSM Evaluation System. International Journal of Engineering \& Technology, Vol. 7(1.6), pp. 17-19.

[4] Pontan, D., Surjokusumo, S., Johan, J., Hasyim, C., Setiawan, M.I., Ahmar, A.S. \& Harmanto, D. (2018). Effect of The Building Maintenance and Resource ManagementThrough User Satisfaction of Maintenance. International Journal of Engineering \& Technology, Vol 7(2), pp. 462-465.

[5] Fauzy, F.A.A., Shah, Z.A., Saedudin, R.R., Kasim, S., Azadin, A.A., Ahmar, A.S. \& Hidayat, R. (2018). Registration System and UTM Games Decision Using the Website Application. International Journal of Engineering \& Technology, Vol. 7(2.2), pp. 45-47.

[6] Iskandar, A., Virma, E. \& Ahmar, A.S. (2019). Implementing DMZ in Improving Network Security of Web Testing in STMIK AKBA. International Journal of Engineering \& Technology, Vol. 7 (2.3), pp. 99-104.

[7] Abdullah, D., Zarlis, M., Napitupulu, D., Hartono, H., Sriadhi, S., Erliana, C. I., ... \& Ahmar, A. S. (2018). A Slack-Based Measures within Group Common Benchmarking using DEA for Improving the Efficiency Performance of Departments in Universitas Malikussaleh. MATEC Web of Conferences, Vol. 197, pp. 16005. EDP Sciences.

[8] Ersoy, M. \& Çelebi, N. (2018). Development of Mining Management Information System for Soma Open Pit Mines. Mine Planning and Equipment Selection, Vol. 2000, pp. 805-810. Routledge.

[9] Saeed, S., Jhanjhi, N.Z., Naqvi, M. \& Humayun, M. (2019). Analysis of Software Development Methodologies. International Journal of Computing and Digital Systems, Vol. 8(5), pp. 446-460.

[10] Fadallah, M.F. \& Rosyida, S. (2018). Program Pemesanan Percetakan Berorientasi Objek dengan Pemodelan Unified Modeling Language. Jurnal Sistem Informasi STMIK Antar Bangsa, Vol. 7(1), pp. 61-70.

[11] Hartono, J.K. (2016). Perancangan Sistem Informasi Akuntansi Berbasis Komputer Pada Toko Listrik Hts Jaya Dengan Menggunakan Metode Rapid Application Development (RAD) [Doctoral Dissertation]. Unika Soegijapranata.

[12] Benmoussa, K., Laaziri, M., Khoulji, S., Larbi, K.M. \& El Yamami, A. (2019). A New Model for the Selection of Web Development Frameworks: Application to PHP Frameworks. International Journal of Electrical and Computer Engineering, Vol. 9(1), pp. 695-703. 
[13] Mediana, D. (2018). Rancang Bangun Aplikasi Helpdesk (A-Desk) Berbasis Web Menggunakan Framework Laravel (Studi Kasus di PDAM Surya Sembada Kota
Surabaya). Jurnal Manajemen Informatika, Vol. 8(2), pp. $75-81$. 